\title{
9-Bartın ili Ulus ilçesi Uluköy ve Zafer köyleri mikrotoponimleri ve dil incelemesi
}

Anıl ÇELİK

Rümeysa UYSAL 2

\begin{abstract}
APA: Çelik, A.; Uysal, R.:(2020). Bartın ili Ulus ilçesi Uluköy ve Zafer köyleri mikrotoponimleri ve dil incelemesi. RumeliDE Dil ve Edebiyat Araştırmaları Dergisi, (21), 151-169. DOI: 10.29000/rumelide.839140.
\end{abstract}

\section{$\ddot{O} \mathbf{z}$}

Belirli bir bölgede yaşayan insanların o bölgede bulunan coğrafi şekillere verdikleri adlandırmaları köken ve yapı bakımından inceleyen bilim dalına mikrotoponimi denir. Mikrotoponimi, toponiminin bir alt kolu olup silikyeradbilim adıyla da karşılık bulmaktadır. Mikrotoponimler, yöre halkının sosyal yaşantısını ve ağız özelliklerini yansıtır, o yöre ve kültürüyle ilgili önemli verileri bünyesinde barındırır. Bu çalışma, Bartın’ın Ulus ilçesine bağlı Uluköy ve Zafer yörelerinin mikrotoponimleri üzerine yapılan bir toponimi çalışmasıdır. Çalışmanın amacı bölgede sözlü kültür ile varlığını sürdüren adlandırmaların kayıt altına alınarak unutulmasını engellemek ve bölgede yer alan zengin dil varlığını korumaktır. Yöreden toplam yüz altmış bir yer adı derlenmiştir. Malzemelerin, "Yer Adlarının Türleri” ve "Leksikosemantik İnceleme” başlıklı iki temel bölümde incelendiği çalışma, bölgeden elde edilen malzemeler aracılığıyla ortaya çıkarılmıştır. "Leksikosemantik İnceleme” bölümünde sahada kayıt altına alınan yer adları, türleri göz önünde bulundurularak tasnif edilmiştir. Tasnif esnasında mikrotoponimlerin hangi yöreye ait olduğunun daha iyi anlaşılabilmesi için yer adlarından sonra ilgili yöre adı kısaltmalar ile ayraç içine alınarak belirtilmiştir. "Leksikosemantik İnceleme" bölümünde ise yöreden derlenen yer adları leksikosemantik açıdan incelenerek bu isimlendirmelerin anlamlarına ulaşılmaya çalışılmıştır. Yer adları öncelikli olarak yöre halkının yer adı hakkında verdiği bilgiler doğrultusunda sınıflandırılmış, gerek görülen yerlerde çeşitli sözlüklerden yararlanılarak yer adlarının anlamı açıklanmıştır. "Sonuç" bölümünde ise elde edilen istatistiksel veriler dikkatlere sunulmuş ve tartışılmıştır.

Anahtar kelimeler: Bartın, Uluköy, Zafer köyü, mikrotoponimi, dil incelemesi

\section{The linguistic analysis of microtoponyms of Uluköy and Zafer villages in the district of Ulus in Bartın}

\begin{abstract}
Microtoponymy is a branch of science that studies the nomenclature of people living in a particular region in terms of origin and structure. It is a sub-branch of toponymy and corresponds to the term "silikyeradbilim" in Turkish. Microtoponyms reflect the social life and dialectological characteristics of the local people and contain important data about that region and its culture. This study is a toponym research on the microtoponymies of Uluköy and Zafer villages of Ulus, Bartın. The aim of the study is to prevent the oblivion of oral culture and nomenclature in the region and to preserve

1 Dr. Öğr. Üyesi, Bartın Üniversitesi, Edebiyat Fakültesi, Türk Dili ve Edebiyatı Bölümü, Yeni Türk Dili ABD, (Bartın, Türkiye), acelik@bartin.edu.tr, ORCID ID: oooo-0001-6035-5303 [Araştırma makalesi, Makale kaylt tarihi: 01.10.2020-kabul tarihi: 20.12.2020; DOI: 10.29000/rumelide.839140]

$2 \quad$ Bartın Üniversitesi, Edebiyat Fakültesi, Türk Dili ve Edebiyatı Bölümü (Bartın, Türkiye) rumeysaaa67@gmail.com ORCID ID: 0000-0001-7039-6002
\end{abstract}

Adres
Address

İstanbul Medeniyet University, Faculty of Education Sciences,

Turkish and Social Scinces Education, Turkish Language Teaching

Education, Cevizli Campus, Kartal-İstanbul /TURKEY

e-mail: editor@rumelide.com 
The linguistic analysis of microtoponyms of Uluköy and Zafer villages in the district of Ulus in Bartın / A. Çelik; R. Uysal (pp. 151-169)

\begin{abstract}
the rich language presence in this area. A total of one hundred and sixty-one place names have been compiled from the locality. The study, in which materials are examined in two basic sections entitled "Types of Place Names" and "Lexico-Semantic Examination", was revealed through materials obtained from the region. The place names recorded in the field have been classified by taking their types into consideration in the "Lexico-Semantic Analysis" section. During the classification, in order to better understand which region the microtoponyms belong to, the relevant region name is indicated after the place names by putting them in brackets with abbreviations. In the "Lexico-Semantic Examination" section, the place names collected from the region are examined in terms of lexico-semantics and the meanings of these names are tried to be reached. Place names are primarily classified in line with the information given by the local people about the place name, and the meaning of the place names was explained using various dictionaries where necessary. In the "Results" section, the statistical data obtained are brought to attention and discussed.
\end{abstract}

Keywords: Bartın, Uluköy, Zafer, microtoponymy, language analysis

\title{
1. Giriş
}

Mikrotoponimi, toponiminin alt kollarından biridir. Yalnızca belirli bir bölgede yaşayan insanların bildiği; haritalarda, sözlüklerde ve tarihî kaynaklarda varlığından söz edilmeyen dağ, tepe, dere, pınar, kuyu, mağara, koy, körfez gibi coğrafi şekillere verilen adları bölge halkının verdiği isimlendirmeler doğrultusunda yapı, anlam ve köken bakımından inceler (Köse, 2014:1). Mikrotoponimler, yalnızca bir bölgeye özgü isimlendirmeler olduğundan yöre halkı dışındaki kullanımı sık değildir. İnsanoğlu varoluşundan bu yana yaşadığı doğayı anlamlandırma çabası içindedir. Yaşam alanını benimsemesi, kendini o bölgeye ait hissetmesinin bir neticesi olarak alanları isimlendirme gereksinimi duyar. Coğrafi şekiller halk arasında isimlendirilerek bir kimlik kazanır ancak değişen hayat şartları, göç vb. sebeplerden dolayı mikrotoponimlerin unutulması söz konusu olabilmektedir. Sözlü kültürde halkın hafızası ve kullanım sıklığıyla yaşayan bu yer isimleri, nesilden nesile aktarılarak varlığını sürdürür (Erkol, 2013:1). İsimlerin pek çoğu yalnızca halk arasında kullanıldığından harita ve yazılı kaynaklarda tespit edilen, kayıtlı yer adlarından sayıca daha fazladır. Mikrotoponimi çalışmaları bu noktada devreye girer. Resmî kaynaklarda ismi zikredilmemiş pek çok isimlendirmeye halk kullanımlarında rastlamak mümkündür. Yer adlarının tespiti sırasında sahada derleme çalışması yapılması incelemenin sağllklı sonuçlar vermesi için en önemli temel ilkedir.

Ülkemizde hâlâ birçoğu saklı, keşfedilmeyi bekleyen zengin dil hazineleri gizliden gizliye varlığını sürdürmekte ve üzerinde yeterince çalışma yapılamadığı için sözlü kültür ürünü olarak kalmaktadır. Mikrotoponimi (silikyeradbilim) alanında yeterli sayıda çalışma yapılamamış olmasının başlıca sebebi bu alanın birçok bilim dalının ortak ilgi alanına girmesi ve disiplenlerarası bir çalışma metodu gerektirmesidir (Köse, 2014:1).

\section{Amaç}

"Bartın İli Ulus İlçesi Uluköy ve Zafer Köyleri Mikrotoponimleri ve Dil İncelemesi” adlı bu çalışma Ulus ilçesine bağlı Uluköy ile Zafer köyünde yer alan mikrotoponimlerin derlenmesiyle oluşturulmuştur. Çalışmanın amacı, bölgedeki yer adı verme kültürünün zamanla unutularak yok olmasına engel olmaktır. Her bölge, coğrafi obje, içinde yaşayan insanlardan bir parça taşır. Yöre halkı kendine has kültürel, etnik ve geleneksel niteliklerini yaşam alanına dâhil eder. Örneğin, bahsi geçen

\footnotetext{
Adres $\mid$ Address

İstanbul Medeniyet Üniversitesi, Eğitim Bilimleri Fakültesi, Türkçe İstanbul Medeniyet University, Faculty of Education Sciences, ve Sosyal Bilimler Eğitimi Bölümü, Türkçe Eğitimi ABD Cevizli Turkish and Social Scinces Education, Turkish Language Teaching Kampüsü, Kartal-İstanbul/TÜRKIYE $\quad$ Education, Cevizli Campus, Kartal-İstanbul /TURKEY e-posta: editor@rumelide.com 1 e-mail: editor@rumelide.com
} 
köylerde birbirini tamamlayan ortak su kaynakları bulunmaktadır fakat hiçbir köy civar köylerin kullandığı ismi kullanmayı tercih etmemiştir. Her köy, yaşadığı alanı kendi kültürel yapısı ve kullanım şekline bağlı olarak isimlendirmiş, böylece ad verme geleneğinin özgün yapısını korumuştur. Halk arasında, sözlü gelenekle yaşatılan bu kültürün karşılaştı̆̆ı en büyük sorun, kayıt altına alınamaması ve zamanla unutulma tehlikesi içerisinde olmasıdır. Bu sebeple mikrotoponimi çalışmaları sıklık kazanmalı, değeri pek az bilinen bu zengin dil hazineleri üzerinde daha çok durulmalıdır. Sahada derleme sırasında bölgeyi iyi bilen yaşlılar, avcılar, çobanlar ile iletişim kurulması çalışmanın daha sağlıklı bir sonuç vermesini sağlayacaktır ancak değişen hayat şartları göç, ölüm vb. beklenmeyen durumlar da göz önünde bulundurulmalıdır. Bölgeyi iyi bilenler hayattan ayrılmadan önce söz konusu veriler derlenmelidir.

\section{Yöntem ve sinırlılıklar}

Bu çalışmada mikro bir yerleşim yeri olan Uluköy ve Zafer köyleri içindeki yer adları ele alınmıştır. Yer adları tespit edilirken Zafer köyü doğumlu Mustafa Şenol (79) ve Uluköy doğumlu Adil Turgut (72) ile yüz yüze görüşme yapılarak, kaynak kişilerin sesleri izin dâhilinde kayıt altına alınarak elde edilen bilgiler ışığında söz konusu yer adları tek tek gezilerek sahada derleme çalışması yapılmıştır.

Araştırma alanı olarak Ulus ilçesine bağlı Uluköy ve Zafer köylerinin tercih edilmesinin nedeni, bölgenin engebeli, dağlık bir yerleşim yeri üzerine kurulmuş olması, doğal tabiatının bozulmaması, dış etkenlerden kendini muhafaza etmiş olması sebebiyle adbilim açılsından keşfedilmeyi bekleyen değerli malzemeler barındırması tespitleridir. Zafer köyü, zengin ormanlara ve bozulmamış bir tabiata sahiptir. Köy halkı geçimini uzun yıllar boyunca ormancılıkla sürdürmüştür. Bundan dolayı bölgede, coğrafi konumunun da bir neticesi olarak orman içleri halk arasında bölümlere ayrılmıştır.

Sinıflandırma sırasında Şahin'in (2011, 2013) ve Erkol'un (2013) konuyla ilgili çalışmalarından faydalanılmıştır. "Leksik- Semantik İnceleme" başlıklı üçüncü bölümde mikrotoponimlerin (silikyeradı) anlamları ve adların veriliş sebepleri tespit edilmiştir Leksik- semantik incelemenin temelini, köy halkı ile görüşülerek kaynak kişilerin verdiği bilgiler oluşturmaktadır. Mikrotoponimlerde kullanılan kelimelerin anlamları ya da coğrafi şeklin bulunduğu yer konusunda şüpheye düşüldüğü durumlarda ise bilgi, haritalar incelenerek ya da üçüncü şahıslara danışlarak doğrulanmaya çalışılmıştır. Şüpheye düşülen ya da yer adının veriliş sebebinin tespit edilemediği durumlarda, veriliş sebepleri de dikkate alınarak bir sonuç elde edilmesi denenmiştir.

Çalışmaya kaynaklık etmeleri bakımından İbrahim Şahin’in (2011) "Yeradıbilimi Araştırmalarında Mikrotoponiminin Yeri, Önemi ve Araştırma Yöntemi: Tırnak Köyü (İçel/Gülnar) Örneği”, Ömer Yağmur'un (2014) "Höbek Köyü Yer Adları Üzerine Bir İnceleme”, Ayşegül Kuşdemir’in (2017) "Yerköy'de Bitki Adlarından Oluşan Yer Adları" ve "Yerköy Mikrotoponimlerinde Görülen Coğrafi Terimler", Merve Yorulmaz Kahve'nin (2018) "Muğla Yer Adları Üzerine Bir Dil İncelemesi Menteşe'deki Silikyeradları" (2018), Cevdet Yılmaz ve Mutlu Kaya'nın (2018) "Bir Mikrotoponimi Denemesi Ayancık'ta Zingal Orman İşletmesi'nin Yer Adlarına Etkisi” (2018) ve Ghadeer Mohammed Qasım Barem'in (2018) "Telafer Mikrotoponimleri ve Dil İncelemesi” isimli çalışmalarının da burada isimlerinin zikredilmesi yararlı olacaktır.

\footnotetext{
Adres Address

İstanbul Medeniyet Üniversitesi, Eğitim Bilimleri Fakültesi, Türkçe İstanbul Medeniyet University, Faculty of Education Sciences, ve Sosyal Bilimler Eğitimi Bölümü, Türkçe Eğitimi ABD Cevizli $\quad$ Turkish and Social Scinces Education, Turkish Language Teaching Kampüsü, Kartal-İstanbul/TÜRKIYE $\quad$ Education, Cevizli Campus, Kartal-İstanbul /TURKEY e-posta: editor@rumelide.com $\mid$ e-mail: editor@rumelide.com
} 


\section{Yer adlarının türleri}

Bu bölümde sahada kayıt altına alının yer adları, türlerine binaen tasnif edilmiştir. Sınıflandırma sırasında mikrotoponimlerin ait oldukları yörelerin daha iyi anlaşılabilmesi amacıyla yer adlarından sonra ilgili yöre adı kısaltmalar ile ayraç içine alınarak belirtilmiştir. Terimlerin açıklanması noktasında İbrahim Şahin'in "Türkiye Yer adbiliminde Terim ve Tür Sınıflandırması Sorunları" (2013) başlıklı makalesinden ve Fadime Erkol'un "Afyonkarahisar İli Çay İlçesi Mikrotoponimleri ve Dil İncelemesi” (2013) adlı yüksek lisans tezinden yararlanılmıştır. Derleme sırasında bazı yer adlarının birden fazla özel ad ile isimlendirildiği tespit edilmiştir. Bu şekildeki yer adlarını ifade etmek için "koşut" terimi tercih edilmiştir. Koşutu mevcut olan adlar büyük ayraç kullanılarak gösterilmiştir. Bölüm; oykonimler, oronimler, horonimler, agroonimler, hidronimler ve drimonimler olmak üzere 6 kısımda ele alınmıştır. Çalışmada 158 tane yer adı bulunmaktadır.

\subsection{Oykonimler}

Yerleşim yeri olarak nitelendirilen tüm yerleşimlerin özel ismidir (Şahin, 2013:52). "Orun adı" olarak karşılık bulmaktadır. Yerleşim yerlerinin özel adları sınıflandırılırken elde edilen bulgular doğrultusunda komonim ve orpedyonim ile sınırlı tutulmuştur. Yöreden toplam 23 tane oykonim derlenmiştir.

\subsubsection{Komonimler}

Komonim, bütün köy yerleşimlerinin özel adıdır (Şahin, 2013:52). Komonimler dört grupta değerlendirilir; bu gruplar; çiftlik adları, köy adları, ören adları ve tol adlarıdır. Çalışmadaki sinıflandırma, köylerin özel isimleri ile sınırlı tutulmuştur.

Köy adları: Bölgeden 2 adet köy adı derlenmiştir; Zafer [Koşut Helkeme], Uluköy.

Çiftlik adları: Bölgeden 1 adet çiftlik adı derlenmiştir; Ganlıhızar (Ulu.).

Ören/ Harabe adları: Yörede harabe "yıkık, artık kullanımda olmayan, virane olan yapı” (Türk Dil Kurumu, 2020) anlamında kullanılmaktadır. Bölgeden 3 adet ören adı derlenmiştir: Gubuscaniñdeğirmeni (Ulu.), Ovalffevziniñdeğirmeni (Zfr.), Sarıçiçekgalesi (Zfr.).

\subsubsection{Orpedyonimler}

Orpedyonim, "Yılın belli dönemlerinde kullamılan (yaylak, kışlak) yerlerin özel adlarıdır." (Şahin, 2013:52).

Yayla adları: Bölgeden toplam 17 adet yayla adı derlenmiştir; Kocıbohcacınıñyanı (Ulu.), Kokurdanyaylası (Zfr.), Gezenyaylası (Zfr.), Sarıçiçekyaylası (Zfr.), Durnayaylası (Zfr.), Findıcakyaylası (Zfr.), Daşboğazyayla (Zfr.), Küçükyazıyaylası (Zfr.), Sabandemürüyaylası (Zfr.), Grrıyaylası (Zfr.), Candarmamezaliiyaylası (Zfr.), Kiralcayaylası (Zfr.), Istrganlkyaylası (Zfr), Böyükdüzyaylası (Zfr.), Yasıkköyyaylası (Zfr.), Baklabostanyaylası (Zfr.), Gabalaghıyaylası (Zfr.). 


\subsection{Oronimler}

"Yer adlarmin bir türü olup yeryüzünde bulunan dă̆, tepe, vadi, yar, uçurum, yumuk (kanyon), geçit, ova vb. her türlü yükseltinin, girintinin, kabarlkhkların, engebelerin özel adların ifade eder" (Şahin, 2013:52). Derleme sonucunda oronimler; bayır adları, boğaz adları, burun adları, dağ adları, ova adları, kaya/ taş adları, kır adları, tepe adları, sırt adları, yar/uçurum adları olmak üzere 10 alt grupta değerlendirilmiştir. Çalışmada 34 tane oronim mevcuttur.

Bayır adları: Çalışma sahasında "bayır" ve "düz" kelimeleri, "eğimli alan” karşllı̆ında kullanılır. Bölgeden 2 adet bayır adı derlenmiştir; Yaylaköyübayırı (Zfr.), Ahmedağdüzü (Zfr.).

Boğaz adları: Yöre halkı yağmur sonrası biriken suyun, su yolu olması hadisesini "boğaz" olarak nitelendirmektedir. Bölgeden 1 adet boğaz adı derlenmiştir; Dereboğazı (Zfr.).

Burun adları: Bölgede, "burun" terimi "yokuşta kalan yer" anlamını taşırken aynı zamanda bu anlamından farklı olarak "iki kenarın kesiştiği yer" anlamında da kullanılmaktadır. Bölgeden 5 adet burun adı derlenmiştir; Burunüstü (Zfr.), Bıçakburnu (Zfr.), Gökceyoguşu [Koşutu Gökceburnu], Enviyeburnu (Zfr.).

Ova adları: Yörede düz olan yerler "ova" olarak adlandırılır. Derleme yapılan bölge, engebeli bir yerleşim yeri olduğundan dolayı sık rastlanan bir isimlendirme değildir. Bölgeden 2 adet ova adı derlenmiştir; Helkemeovası (Zfr.), Katırovası (Zfr.).

Kaya/ Taş adları: Yöre halkı yerleşim yerindeki "büyük ve sert taş kütleleri”ni (Türk Dil Kurumu, 2020) kaya anlamında kullanmaktadır. Bölgeden 5 adet kaya adı derlenmiştir; Yanıggaya ( $Z f r$.), İnbaşıgayası (Zfr.), Dervetgayası (Zfr.), Arıgayası (Ulu.), Bacagcıgaya (Zfr.).

Kır adları: Yörede "bayırda, yamaçta kalan, ekilmemiş, tarıma elverişsiz arazi" (Türk Dil Kurumu, 2020) olarak ifade edilmektedir. Bölgeden 4 adet kır olarak görülen yer adı derlenmiştir: Kırharman (Ulu.), Karacasu (Zfr.), Kelebektarlası (Zfr.), Harmanaltı (Zfr.).

Sırt adları: Yörede sirt kelimesi “dağın zirvesi boyunca uzanan, yüksekte kalan kısım” (Türk Dil Kurumu, 2020) anlamında kullanılmaktadır. Bölge engebeli ve dağlık bir araziye sahiptir. Bölgede birçok sırt bulunsa da büyük bir kısmı içerisinde sırt kelimesinin geçtiği yer adbilimcil yapılarla oluşturulmamıştır. Yörede bu yerler sırt boyunca uzanan yayla isimleriyle bilinmektedir. Bundan dolayı bu yerler yayla adları bölümünde değerlendirilmiştir.

Tepe adları: Bölgeden 11 adet tepe adı derlenmiştir; Çelikbaştepesi (Zfr.), Gülleyigtepesi (Zfr.), Kilseyanıtepesi (Zfr.), Gökgözgıră̆ı (Zfr.), Kapahlıdă̆ (Zfr.), Ucbuñargirağı (Zfr.), Ceyüplertepesi (Zfr.), Türbetepesi (Zfr.), Sivricegayatepesi [Koşutu Sivriburnu] (Zfr.), Konacukgirağı (Zfr.).

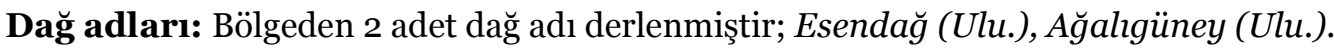

Yar/Uçurum adları: Bölgede “dip” sözcügü “yar” anlamında kullanılmaktadır. Yöreden 2 tane yar/uçurum ismi toplanmıştır; Atakdibi (Ulu.), Yardibi (Ulu.).

\footnotetext{
Adres $\mid$ Address

İstanbul Medeniyet Üniversitesi, Eğitim Bilimleri Fakültesi, Türkçe İstanbul Medeniyet University, Faculty of Education Sciences, ve Sosyal Bilimler Eğitimi Bölümü, Türkce Eğitimi ABD Cevizli Turkish and Social Scinces Education, Turkish Language Teaching Kampüsü, Kartal-İstanbul/TÜRKIYE $\quad$ Education, Cevizli Campus, Kartal-İstanbul /TURKEY e-posta: editor@rumelide.com 1 e-mail: editor@rumelide.com
} 

151-169)

\subsection{Horonimler}

"Toponiminin bir kolu olup ülke, bölge, il, ilçe gibi idari sinırları olanca belirli bir bölge, coğrafya gibi resmi stnurları olmayan fakat duyulduğunda insanlarm kafasında belirli bir anlam ifade eden yani doğal sinırları olan özel adlar ifade eder" (Şahin, 2013:54). Bölgeden toplam 8 adet horonim derlenmiştir.

\section{Yatak adları}

Kısa süreli kalınan yatak adları: Yöre halkı "ormanda iş yapan kimselerin kaldığı alan" anlamında "sayvan" ya da "güme" adlarını kullanmaktadır. Yörede insanlar coğrafi şartların bir getirisi olarak geçiminin büyük bir kısmını ormanda çalışarak sağlamaktadır. Bundan dolayı orman içinde ihtiyaca yönelik, dönemsel olarak kullanılan, ağaç kabuklarından barınaklar yapılmıştır. Bölgeden 4 adet sayvan/ güme, yatak adı derlenmiştir; Garaosmanınyatağı (Zfr.), Gabuksayvanı (Zfr.), Kadıoglugümesi [Koşutu Kadıgümesi] (Zfr.).

Hayvanlarla ilgili yataklar: Bölgede bu tür isimlendirmelerin bulunduğu yere göre çeşitlilik gösterdiği görülür. Bu yataklar, ormanda, "çul" / "gelik" olarak adlandırılır ve üstü açık, köknar ağacından yapılan iki direğin etrafı germeç (tel) ile çevrili, büyükbaş hayvanlar için kullanılan yataklardır. Köyde ise bu yataklar "ahır" olarak isimlendirilir. Bölgeden 4 adet yatak adı derlenmiştir; Bızagahırı [Koşutu Kiler (Zfr.)], Goyunahırı (Zfr.), Kömüşyatağı (Zfr.).

\subsection{Agroonimler}

"Tarımın yapıldı̆̆ı irili ufaklı tüm alanlara agroonim denir" (Şahin, 2013:54). Agroonimler, 5 kategoride ele alınmıştır. Yöreden 31 tane agroonim toplanmıştır.

Băg adları: Yöre halkı üzüm bağlarını çeşitlerine göre isimlendirmektedir. Bölgeden 4 adet bağ adı derlenmiştir; Çilyenüzüm (Zfr.), Gökceüzüm (Zfr.), Çavuşüzüm (Zfr.), Garaüzüm (Zfr.).

Bahçe adları: Bölgeden 3 adet bahçe adı derlenmiştir; Aşşaabagce (Zfr.), Yukarıbagce (Zfr.), Akçakirenbagce (Zfr.).

Çamlık adları: Bölgeden 5 adet çamlık adı derlenmiştir; Ayıniñçamlı̆̆ (Ulu.), Külahçıçamlığı (Zfr.), Sarıçamlık (Zfr.), Garaçamlık (Zfr.), Öteçayır (Zfr.).

Çayır adları: Yörede çayır kelimesi "hayvanların otladığı, ekilmeyen, boş alan" anlamında kullanılmaktadır. Bölgeden 5 adet çayır adı derlenmiştir; Çayırbaş (Ulu.), Kiliseyanı (Ulu.), Gölbuñarçayırı (Zfr.), Aşşaaçayır (Zfr.), Yukarıçayır (Zfr.).

Tarla adları: Bölgede tarla sözcüğü "sürülen, ekim yapılan, verimli görülen alan" manasını taşımaktadır. Çalışmada kalıcı mikrotoponimlerin değerlendirilmesi sebebiyle sahibi değişse bile adı değişmeyen tarlalar esas alınmıştır. Bölgeden 14 adet tarla adı derlenmiştir; Isbagköytarlası (Ulu.), Arıglar (Ulu.), Ulugaya (Ulu.), Köründeğirmenyanı (Zfr.), Garadikentarlası (Zfr.), Pirehasaniñtarlası (Zfr.), Abdalhızarı (Zfr.), Garabaglıktarlası [Koşutu Erbakaniñtarla (Zfr.)], Değirmendaşıtarlası [Koşutu Harmanaltı (Zfr.)], Çukurtarla (Zfr.), Gavurevitarlası (Zfr.), Gortarla (Zfr.).

\footnotetext{
Adres $\mid$ Address

İstanbul Medeniyet Üniversitesi, Eğitim Bilimleri Fakültesi, Türkçe İstanbul Medeniyet University, Faculty of Education Sciences, ve Sosyal Bilimler Eğitimi Bölümü, Türkce Eğitimi ABD Cevizli Turkish and Social Scinces Education, Turkish Language Teaching Kampüsü, Kartal-İstanbul/TÜRKIYE $\quad$ Education, Cevizli Campus, Kartal-İstanbul /TURKEY e-posta: editor@rumelide.com 1 e-mail: editor@rumelide.com
} 


\subsection{Hidronimler}

Hidronim, "gerek doğal yolla oluşmuş gerekse yapay yolla meydana getirilmiş her türlü su varlığını adın ifade eder." (Şahin, 2013:53). Kendi içinde potamonim, limnomonim ve helonim olmak üzere 3 başlık altında incelenir. Bölgeden toplam 55 adet hidronim derlenmiştir.

\subsubsection{Potamonimler}

"Bütün nehirlerin, ırmakların, çayların, derelerin özel adını ifade eder." (Şahin, 2013:53). Çalışmadaki potamonimler, derlemede elde edilen bulgular doğrultusunda aşağıdaki 4 kategoride tasnif edilmiştir. Yöreden 41 tane potamonim toplanmıştır.

Çay adları: Yöreden 3 tane çay adı toplanmıştır; Helkemeçayı (Zfr.), Arıgayaçayı [Koşutu Uluköyçayı (Ulu.)].

Çeşme adları: Bölgeden 12 adet çeşme adı derlenmiş̧ir; Hasaniñçeşme (Ulu.), Aşşaaköyçeşmesi (Ulu.), Gocaahmediñçeşmesi (Zfr.), Garahaliliñçeşmesi (Zfr.), Hilmiaslançeşmesi (Zfr.), Hüseyincingözçeşmesi (Zfr.), Durmuşhüseyingüleçeşmesi (Zfr.), Horozahmediñçeşmesi (Zfr.), Hacıhakkıninçeşmesi [Koşutu Hachakkıniñsuyu (Zfr.)], Muhammediñçeşmesi (Zfr.), Garadaghniñçeşmesi (Zfr.).

Dere adları: Coğrafi olarak dere, "genellikle yazın kuruyan küçük akarsu, iki dağ arasındaki uzun çukur"(Türk Dil Kurumu, 2020) anlamında kullanılmaktadır. Yörede "dere" kelimesinin yanı sıra "su" kelimesi de iki dağ arasındaki çukuru karşılamak için kullanılmaktadır. Yöreden 15 tane dere adı toplanmıştır; Aloğluderesi (Ulu.), Sapdere [Koşutu Kazaskeroğluderesi (Zfr.)], Egrigürgenderesi (Zfr.), Kizılagacsuyu (Zfr.), Esmirderesi (Zfr.), Ulacderesi (Zfr.), Hudumboğuderesi (Zfr.), Döngelderesi [Koşutu Gocadere (Zfr.)], Sartmsaklıdere (Zfr.), Velideresi (Zfr.), Gülleyigsuyu (Zfr.), Uluköyderesi [Koşutu Arrgayaçayı (Ulu.)].

Pınar adları: Bu kategoride "pınar" sözcüğünün koşutu olan "oluk/uluk" kelimesi ile yörede "su yolu" anlamıda kullanılan "arg" kelimesi bir arada verilmiştir. Bölgeden 11 adet pınar adı derlenmiştir; Taşpınar (Ulu.), Demircioğlubuñarı (Zfr.), Kirenyambuñarl (Zfr.), Garadikenbuñarı (Zfr.), Karacasubuñarı (Zfr.), Olukbaşı [Koşutu Değirmenoluğu (Zfr.)], Dogguzoluklar (Zfr.), Demirulug (Zfr.), $\operatorname{Arg}(Z f r)$, Karacasusuyu (Zfr.).

\subsubsection{Limnomonimler}

"Su adı" sinıflandırmasının bir alt türü olan limnomonimler, tüm göllerin, göletlerin, kuyu ve havuzların özel adıdır (Şahin, 2013:53). Bu kısım 2 kategoride ele alınmıştır. Yöreden 10 tane limnomonim toplanmıştır.

Göl adları: Yöredem 5 tane göl adı toplanmıştır; Goyungölü (Zfr.), Sazlk (Zfr.), Uluagacaltı [Koşutu Ulacaltı (Zfr.)], Gocagöl (Zfr.).

Kuyu adları: Terim olarak "kuyu" kelimesi "yeraltı sularindan yararlanmak üzere, insan eliyle açılmış, genellikle çember biçiminde derin çukur” (Türk Dil Kurumu, 2020) olarak tanımlanmaktadır. Yörede "kuyu" kelimesi "muar" kelimesiyle de ifade edilmektedir. Bölgeden 5 adet kuyu adı

\footnotetext{
Adres $\mid$ Address

İstanbul Medeniyet Üniversitesi, Eğitim Bilimleri Fakültesi, Türkçe İstanbul Medeniyet University, Faculty of Education Sciences, ve Sosyal Bilimler Eğitimi Bölümü, Türkce Eğitimi ABD Cevizli Turkish and Social Scinces Education, Turkish Language Teaching Kampüsü, Kartal-İstanbul/TÜRKIYE $\quad$ Education, Cevizli Campus, Kartal-İstanbul /TURKEY e-posta: editor@rumelide.com 1 e-mail: editor@rumelide.com
} 
The linguistic analysis of microtoponyms of Uluköy and Zafer villages in the district of Ulus in Bartın / A. Çelik; R. Uysal (pp. 151-169)

derlenmiştir; Kamilonbaşını̃̃kuyusu (Ulu.), Karguyusu (Zfr.), Katırmuarı (Zfr.), Gölmuarı (Zfr.), Gölyanguyusu (Zfr.).

\subsubsection{Helonimler}

Bataklık adları: "Tüm bataklkların, bataklkklaştırılmış yerlerin özel adıdır" (Şahin, 2013:53). Bölgeden 4 adet bataklık adı derlenmiştir; Kirenmuarı (Ulu.), Doñuzçayırı (Zfr.), Garven (Zfr.), Sarıayabatakhı̆ı (Zfr.).

\subsection{Drimonimler}

"Tüm ormanların, orman kısımlarmın, koruluklarm özel adıdı" (Şahin, 2013:53). Bölge dağlık, engebeli bir arazi yapısına sahiptir. Tabiat mirası bakımından oldukça zengin olan bölgede, yöre halkı çok uzun yıllar ormanlarda çalışarak geçimini sağlamıştır. Adlandırma sırasında bölgenin coğrafi özellikleri etkili olmuştur. Bölgedeki ormanlarda çok sayıda bölmeler ve kısımlar bulunmaktadır. Bölgeden 7 adet orman adı derlenmiştir; Derefindık (Zfr.), Kapakhormanı (Zfr.), Sökeormamı (Zfr.), Ardıç (Zfr.), Palaz (Zfr.), Güme (Zfr.), Papazharmanı (Zfr.).

\section{Leksikosemantik analiz}

Bu kısımda kullanılan yer alan kategoriler İbrahim Şahin’in “Türkiye Yer adbiliminde Leksik-Semantik Sinıflandırma Meselesi” (2013) adlı makalesinden ve Fadime Erkol'un "Afyonkarahisar İli Çay İlçesi Mikrotoponimleri ve Dil İncelemesi” (2013) adlı yüksek lisans tezinden yola çıkılarak belirlenmiştir.

Bu bölümde yer adları öncelikli olarak yöre halkının yer adı hakkında verdiği bilgiler doğrultusunda sınıflandırılmış, gerek görülen yerlerde çeşitli sözlüklerden yararlanılarak yer adlarının anlamı açıklanmıştır. Sınıflandırma sırasında derlenen yer adları yöre halkının telaffuzuna göre kaydedilmiştir. Yer adlarının hangi yöreye ait olduğu derlenen yerin kısaltması ayraç içinde belirtilmiştir. Koşutu olan yer adlarına gönderme yapılırken gönderme yapılan yer adının bulunulduğu alt başlı̆̆ın numarası dikkate alınmıştır.

\section{1. İnsan ve insan etkinlikleri ile coğrafyayla ilgili nesnelerin bağlantılarını direkt olarak aksettiren yer adları}

\subsubsection{Antropotoponimler}

$\mathrm{Bu}$ kısımda; kimselerin ismi, soyismi, lakabı ve unvanından oluşan yer adları ele alınmıştır. Antropotoponimler aşağıdaki dört kategoride incelenmiştir.

\subsubsection{1. Ön adlarla olușanlar:}

Hasanıñçeşme (Ulu.) Hasan+in çeşme. "Düzköy" adlı tarlanın yanında bulunan çeşmeye denilmektedir. Yöre halkı yaptıran kişinin adından dolayı bu adın verilmiş olduğunu söylemektedir.

Hilmiaslançeşmesi (Zfr.) Hilmi Aslan çeşme+si. Yöre halkı bu çeşmenin "Hilmi Aslan" adındaki kişinin hayır amaçlı olarak yaptırdığı, yangın olduğunda kullanılan, depolu bir çeşme olduğunu söylemektedir.

\footnotetext{
Adres | Address

İstanbul Medeniyet Üniversitesi, Eğitim Bilimleri Fakültesi, Türkçe İstanbul Medeniyet University, Faculty of Education Sciences, ve Sosyal Bilimler Eğitimi Bölümü, Türkce Eğitimi ABD Cevizli Turkish and Social Scinces Education, Turkish Language Teaching Kampüsü, Kartal-İstanbul/TÜRKIYE $\quad$ Education, Cevizli Campus, Kartal-İstanbul /TURKEY e-posta: editor@rumelide.com 1 e-mail: editor@rumelide.com
} 
Hüseyincingözçeşmesi (Zfr.) Hüseyin Cingöz çeşme+si. Yaptıran kişinin kendi adını verdiği hayır amaçlı yapılan bir çeşmedir.

Durmuşhüseyingülecçeşmesi (Zfr.) Durmuş- Hüseyin Güleç çeşme+si. Karavelioğlu Mahallesi'nde bulunmaktadır. Yöre halkından elde edilen bilgiye göre Durmuş ve Hüseyin adındaki iki amcaoğlunun hayır amaçlı yaptırdıkları bir çeşmedir.

Muhammediṇ̃çeşmesi (Zfr.) Muhammed+in çeşme+si. Sökü bölgesine giderken yol kenarında bulunan çeşmenin adıdır.

Velideresi (Zfr.) Veli dere+si. Yöre halkı Burunüstü’ne giderken o yol güzergahındaki su birikintisini "Velideresi" olarak adlandırmaktadır. Kırsal kesimin ortalarından geçen bir su birikintisidir. Neden bu şekilde adlandırıldığı net olarak bilinmemektedir. Ancak mahallede "Veli" adında bir kişinin orada bulunan su birikintisi üstüne tahtadan bir köprü yaptırdığı, zamanla bu tahta köprünün suyun ıslatmasıyla çürüdüğü ve köprünün tamamen yıkıldığı, bunun ardından ise bu su birikintisinin adının "Velideresi" olarak anıldığı söylenilmektedir.

Demircioglubuñarn (Zfr.) Demircioğlu pınar+ı. Hayvanların su içtiği oluğun adıdır. Bir demircinin yapması sebebiyle bu şekilde adlandırılmaktadır.

Kamilonbaşınıñkuyusu (Ulu.) Kamil onbaşı+nın kuyu+su. Uluköy, Ömerağ Mahallesi Camii önünde yer alan kuyunun adıdır. Kâmil adında onbaşı bir askerin şehit edilmesi üzerine kuyunun bu şekilde adlandırıldığı söylenmektedir.

\subsubsection{Lakaplarla oluşanlar}

Bacagcıgaya (Zfr.) Bacakçı kaya. Orman içindeki kayanın adıdır. Yöre halkı tarafından adı bilinmeyen bir kişinin bacağı ormanda çalışırken kütük kayması sonucu kırılmıştır. Olayın bu bölgede yaşanması sebebiyle bu şekilde adlandırıldığı söylenmektedir.

Gökgözgırăğ (Zfr.) Gökgöz+ kvrak+ı. Bu tepenin eteklerinde yaşayan insanların gözlerinin gök rengi gibi mavi olması sebebiyle bu şekilde adlandırıldığı söylenmektedir. Tepenin arka kısmında yaşayan köy halkının ise genel olarak gözlerinin kahverengi olduğu belirtilmiştir. Bundan dolayı tepenin eteklerinde yaşayan köy halkı tepenin kendilerine kalan kısmını bu şekilde adlandırmıştır.

Garaosmanyată̆ (Zfr.) Kara Osman yatak+l. Neden bu adın verildiği bilinmemektedir. Yöre halkı ormanda iş yapan kimselerin kaldığı alanı bu şekilde adlandırmaktadır

Kadıoglugümesi (Zfr.) Kadı oğ(u)l+u güme+si. "Candarmamezaliiyaylası" ile "Katırovası" arasında kalan patika yolundaki seferî kimselerin kısa süreli kaldığı yerdir. Yazın hayvanlar ormana çıkarıldığı zaman genellikle üç ay süreyle ormanda kalınması için yapılmıştır. Mustafa Şenol’un dedesi tarafından yapıldığından dolayı, bu kişinin sülale lakabıyla adlandırılmıştır.

Külahçıçamlı̆̆ (Zfr.) Külahçı çamlık+ı. Keloğlu Mahallesi’nde bulunur. Çamlık, fidan yetiştirilen yer olarak kullanılmaktadır. Neden bu şekilde adlandırıldığı bilinmemektedir. 
Körüñdeğirmenyanı (Zfr.) Kör+ün değirmen yan+l. Tarla sahibinin görme engelli olması sebebiyle bu şekilde adlandırılmaktadır. Yöre halkı eskiden tarlanın yerinde suyla çalışan bir un değirmeni olduğunu söylemektedir. Günümüzde sadece un değirmeninin kalıntıları mevcuttur.

Pirehasanıñtarlası (Zfr.) Pire Hasan+ın tarla+sı. Yöre halkı tarlanın "Pire" lakaplı Hasan Ünal'a ait olması sebebiyle bu şekilde adlandırıldığını söylemektedir.

Garadikentarlası (Zfr.) Karadiken tarla+sı. Köründeğirmenyanı’ndan geçtikten sonra orman içinde bulunan tarlanın adıdır. "Garadiken" lakaplı bir kişiye ait olduğu söylenmektedir.

Abdahızarı (Zfr.) Abdal Hzzar+l. Abdaloğlu Mahallesi'nde bulunan tarlanın adıdır. Lakabı "Abdal" olan bir kimseye ait olması dolayısıyla böyle isim aldığı belirtilmektedir. Tarla, kişi öldükten sonra torunu Hasanoğlu Mehmed'e kalmıştır. Ancak Hasanoğlu Mehmed'in Çanakkale Savaşı'nda şehit düşmesi üzerine tarla boş kalmıştır. Hızar, suyla çalışan değirmenin adıdır. Zamanla su hızarı harabe olmuştur.

Gubuscanıñdeğirmeni (Ulu.) Gubusca+nın değirmen+i. Uluköy Değirmenyanı Mahallesi Camii yanındaki harabe olmuş değirmenin adıdır. "Gubusca" lakaplı Osman Turgut adlı kişiye aittir.

Erbakanıñtarlası (Zfr.) Er bakan+in tarla+sı. Yörede "Erbakan” lakaplı Ramazan Ünal'a ait olan tarlanın adıdır. Bu kişi, Necbettin Erbakan'nın siyasî ve fikrî görüşlerini benimsemesinden dolayı "Erbakan” olarak lakap almıştır. Yöre halkı da onun tarlasını lakabıyla adlandırmaktadır.

Gavurevitarlası (Zfr.) Gavur ev+i tarla+sl. Ulac Deresi'nin iki tarafinda yer alan tarlalardan birinin adıdır. Yöre halkı zamanında gayrimüslim birine ait olması sebebiyle bu şekilde adlandırıldırığını söylemektedir.

Gocaahmediñçeşmesi (Zfr.) Koca Ahmet+in çeşme+si. Mille Mahallesi yolu üzerindeki çeşmenin adıdır. Yöre halkı Goca Ahmet lakaplı kişinin boyunun iki metre olması dolayısıyla böyle isimlendirildiği belirtilmektedir.

Garahaliliņ̃̂eşmesi (Zfrr.) Kara Halil+in çeşme+si. Fazal Mahallesi'ndeki çeşmenin adıdır. Yöre halkı Gara Halil lakaplı kişinin esmer olması sebebiyle bu şekilde adlandırıldığını söylemektedir.

Garadaghñņ̃̂eşmesi (Zfr.) Karadağh+nın çeşme+si. Sökü bölgesi yol kenarında bulunan çeşmenin adıdır. Yöre halkı "Karadağlı" lakaplı bir kişi tarafından yapılması sebebiyle bu şekilde adlandırıldığını söylemektedir.

Horozahmediñ çeşmesi (Zfr.) Horoz Ahmet+in çeşme+si. Köy meydanındaki çeşmenin adıdır. "Horoz" lakaplı Ahmet adında bir kişi, bahçesinden çıkan suyu mahalle ortasına getirtip tahtadan bir oluk yaptırmıştır. Kişi tarafından yaptırılması sebebiyle bu şekilde adlandırılmaktadır.

\footnotetext{
Adres $\mid$ Address

İstanbul Medeniyet Üniversitesi, Eğitim Bilimleri Fakültesi, Türkçe İstanbul Medeniyet University, Faculty of Education Sciences, ve Sosyal Bilimler Eğitimi Bölümü, Türkce Eğitimi ABD Cevizli Turkish and Social Scinces Education, Turkish Language Teaching Kampüsü, Kartal-İstanbul/TÜRKIYE $\quad$ Education, Cevizli Campus, Kartal-İstanbul /TURKEY e-posta: editor@rumelide.com 1 e-mail: editor@rumelide.com
} 


\subsubsection{Unvanlarla oluşanlar}

Ahmedağdüzü (Zfr.) Ahmet ağa düz+ü. Kişinin fındık tarlasının adıdır. Bir bayırda bulunmaktadır3. Yöre halkı, tarlanın "Ahmet Ağa" adında bir kişiye ait olması sebebiyle bu şekilde adlandırıldığını söylemektedir.

Hacıhakkıniņ̣̃eşmesi (Zfr.) Hacı Hakkı+nın çeşme+si. Sarıçiçekyaylası'nın bitişiğinde bulunan çeşmenin adıdır. Yöre halkı, Hacı Hakkı lakaplı bir kişi tarafından yaptırılması sebebiyle bu şekilde adlandırdığını söylemektedir4.

\subsubsection{Soyadlarla oluşanlar}

Ulugaya (Ulu.) Ulu kaya. Osman Ulukaya'ya ait olması sebebiyle bu şekilde adlandırılan tarlanın adidır.

\subsubsection{Topotoponimler}

Bu bölümde hidrotoponimler, orotoponimler, oykotoponimler, horotoponimler olmak üzere yer adları 4 başlık altında değerlendirilmiştir.

\subsubsection{Hidrotoponimler}

Helkemeçayı (Zfr.) Helkeme çay+ı. Zafer köyünden geçen çayın adıdır.

Arrgayasıçayı (Ulu.) Arı kaya+sı çay+l. Arıgayası'ndan gelen suyun adıdır5.

Aloğluderesi (Ulu.) Al oğ(u)l+u dere+si. Yöre halkı, Aloğlu Mahallesi yakınından geçmesi sebebiyle bu şekilde adlandırmaktadır.

Gazaskeroğluderesi (Zfr.) Kazasker oğ(u)l+u dere+síb. Yöre halkı, Kazaskeroğlu Mahallesi'nden geçmesi sebebiyle bu şekilde adlandırmaktadır.

Ĕgrigürgenderesi (Zfr.) Ĕ̆ri gürgen dere+si. Tarım alanlarının olduğu bölgede bir tane eğri büyüyen gürgen ağacı olması sebebiyle yöre halkı bu şekilde adlandırmaktadır.

Gızılagacsuyu (Zfr.) Kızıl agaç su+(y)u. Kızılağaç ormanından akan suyun adıdır. Ormanda kızılğaçlar su olan yerlerde yetişir. Diğer birçok ağaç türü susuz yaşayabilirken kızılağaçlar ise yetişmek için suya ihtiyaç duyar. Orman içindeki suyun kızılağaçları beslemesi sebebiyle yöre halkı ormanın içinden akan suyu bu şekilde adlandırmaktadır.

Esmirderesi (Zfr.) Esmir dere+si. Esmir Mevkii'nin altından geçerek tarlalara ulaşan derenin adıdır. Yöre halkı sözü edilen mevkiden geçmesi sebebiyle bu şekilde adlandırmaktadır.

\footnotetext{
3 Yer adındaki “düz” kelimesi “eğimi çok olan yer” anlamında kullanılmıştır. Sözcüğün Derleme Sözlüğündeki anlamlarından biri de "Bayır"dır (Türk Dil Kurumu, 2020).

Yöre halkı tarafindan "Hacıhakkınıñçeşmesi”, "Hacıhakkınıñsuyu” adıyla da bilinmektedir.

Yörede suyun mevsime göre azalması ya da artış göstermesi durumunda zaman zaman "Uluköyçayı/Uluköyderesi” de denilmektedir.

"Kazaskeroğluderesi” için “Sapdere” adı da yaygın olarak kullanılmaktadır.

Adres

İstanbul Medeniyet Üniversitesi, Eğitim Bilimleri Fakültesi, Türkçe ve Sosyal Bilimler Eğitimi Bölümü, Türkce Eğitimi ABD Cevizli Kampüsü, Kartal-İstanbul/TÜRKIYE e-posta: editor@rumelide.com

Address

İstanbul Medeniyet University, Faculty of Education Sciences,

Turkish and Social Scinces Education, Turkish Language Teaching

Education, Cevizli Campus, Kartal-İstanbul /TURKEY

e-mail: editor@rumelide.com
} 
The linguistic analysis of microtoponyms of Uluköy and Zafer villages in the district of Ulus in Bartın / A. Çelik; R. Uysal (pp. 151-169)

Ulacderesi (Zfr.) Ulac dere+si. Tarlaların arasından akan derenin adıdır. Niçin bu şekilde adlandırıldığı bilinmemektedir.

Döngelderesi (Zfr.) Dön gel dere+si. Orman içinde döngel ağacını besleyen derenin adıdır. Orman içinden gelen su, döngel ağacı etrafında birikir. Yöre halkı, döngel ağacını beslemesi sebebiyle bu şekilde adlandırmaktadır7.

Sarmmsaklıdere (Zfr.) Sarımsaklı dere. Esmir Deresi yakınlarında Kulaksızoğlu Mahallesi'ne kadar uzanan derenin adıdır. Niçin bu şekilde adlandırıldı̆̆ı bilinmemektedir.

Hudumboğuderesi (Zfr.) Hudum bok+u dere+si. Saraycık Tepesi'nden Ucsaray sonuna kadar uzanan derenin adıdır. Etrafında tavşan keçi gibi orman hayvanları yaşamaktadır. Yöre sakinleri, "atalardan kalma bu şekilde adlandırılır" vb. ifadelerle derenin niçin bu şekilde adlandırıldığının kesin olarak bilinmediğini belirtir.

Gülleyigsuyu (Zfr.) Gülleyik+tepe+si. Gülleyigtepesi’nden akan suyun adıdır. Yöre halkı suyun tepeden gelmesi sebebiyle bu şekilde adlandırmaktadır.

Taşpınar (Ulu.) Taş pınar. Ömeră̆ Mahallesi içinde akan suyun adıdır. Niçin bu şekilde adlandırdı $\breve{g} ı$ bilinmemektedir.

Demircioglubuñarı (Zfr.) Demirci oğ(u)l+u pınar+l. Hayvanların su içtiği oluğun adıdır. Yöre halkı bir demircinin yapması sebebiyle bu şekilde adlandırmaktadır.

Karacasubuñar (Zfr.) Karaca su pınartı. Karacasu tarlasının içinde bulunan pınarın adıdır. Yazın soğuk kışın sıcak su akmaktadır. Tarlanın adı sebebiyle bu şekilde adlandırılmaktadır.

Değirmenoluğu (Zfr.) Değirmen oluk+u. Arg'ın altında kalan oluğun adıdır. Yöre halkı eskiden burada Bizanslar'dan kalan bir değirmen olduğunu fakat zamanla aşınarak sadece su çıkan yerin kaldığını söylemektedir. Eskiden burada değirmen bulunması sebebiyle bu şekilde adlandırılmaktadır ${ }^{8}$.

Demirulug (Zfr.) Demir oluk. Findıcak tarafında bulunan su deposunun adıdır9.

$\operatorname{Arg}$ (Zfr.) Arg. Su yolunun adıdır. Yöre halkı iki tarlayı birbirinden ayırmak için tarla kenarlarına belirleyici su çukurları açmaktadırlar.

Goyungölü (Zfr.) Koyun göl+ü. Fındıcak Yaylası’nın alt tarafında bulunan gölün adıdır. Yöre halkı hayvanlarını serinletmek için bu göle götürür. Hayvanların girdiği su olarak kullanılması sebebiyle bu şekilde adlandırılmaktadır.

Sazhg (Zfr.) Sazlık. Çukurtarla'nın altındaki yerden çıkma suyun adıdır. Çukur bir alan içerisine su dolması sebebiyle bu şekilde adlandırılmaktadır.

Uluagacaltn (Zfr.) Ulu ăgaç alt+l. Çukurtarla altındaki çukur içine dolan iki sudan birinin adıdır. Tarlanın altına kalması sebebiyle bu şekilde adlandırılmaktadır ${ }^{10}$.

Yöre halkı "Döngelderesi” için "Gocadere" adını da kullanmaktadır.

"Değirmenoluğu", "Olukbaşı" olarak da adlandırılmaktadır.

Su deposunun cinsi sebebiyle bu şekilde adlandırıldığı düşünülmektedir.

Adres

İstanbul Medeniyet Üniversitesi, Eğitim Bilimleri Fakültesi, Türkçe ve Sosyal Bilimler Eğitimi Bölümü, Türkce Eğitimi ABD Cevizli Kampüsü, Kartal-İstanbul/TÜRKIYE e-posta: editor@rumelide.com
Address

İstanbul Medeniyet University, Faculty of Education Sciences,

Turkish and Social Scinces Education, Turkish Language Teaching

Education, Cevizli Campus, Kartal-İstanbul /TURKEY

e-mail: editor@rumelide.com 
Doñuzçayır (Zfr.) Domuz çayır+l. Ardıç düzlüğünde bulunan bataklığın adıdır.

Aşaaköyçeşmesi (Ulu.) Aşağı köy çeşme+si. Uluköy Ömeră̆ Mahallesi'nde bulunan çeşmenin adıdır. Aşağıköylü adı bilinmeyen bir kadın tarafından yaptırılmış olması sebebiyle yöre halkı tarafından bu şekilde adlandırılmaktadır.

\subsubsection{Oykotoponimler}

Ganhhzzar (Ulu.) Kanlı hızar. Uluköy'de bulunan alabalık çiftliğinin adıdır. Yörede "değirmen" anlamında bir "hızar" kelimesi kullanılmaktadır. Yöre halkı eskiden burada değirmen olması sebebiyle burayı bu şekilde adlandırmıştır.

Sarıçiçekgalesi (Zfr.) Sarı çiçek kale+si. Sarıçiçekyaylası'nda bulunan kalenin adıdır. Yöre halkı tarafından içinde bulunduğu yaylanın adı sebebiyle bu şekilde adlandırıldığı düşünülmektedir. Bölgede Rumların yaşadığı zamandan bu yana bu şekilde adlandırıldığı dile getirilmiştir. Günümüzde harabe olmuş durumdadır.

Findecakyaylası (Zfr.) Findık+cak yayla+sı. Gezenyaylası'nın $1 \mathrm{~km}$ ilerisinde Koyungölü ile Daşboğaz arasında yer alan yaylanın adıdır. Yöre halkı, her yerde yetişmeyen yabanî dağ findığının bu yaylada yetişmesi sebebiyle yaylaya bu adı vermiştir.

Gezenyaylası (Zfr.) Gezen yayla+sı. Ardıç bölgesinde yer alan yaylanın adıdır. Düz geniş bir alan olması sebebiyle bu şekilde adlandırılmaktadır.

Daşboğazyaylası (Zfr.) Taş boğaz yayla+sı. Safranbolu - Helkeme arasındaki sırt boyunun adıdır. Hem taşlık bir alana sahip olması hem de iki bölge arasında boğaz gibi boydan boya görünmesi sebebiyle bu şekilde adlandırılmaktadır.

Kokurdanyaylası (Zfr.) Kokurdan yayla+sı. Sirt boyundaki yaylalardan birinin adıdır. Ermenilerin 100 yıl önce buraya gelerek buharlı makine getirmesiyle birlikte o dönemden beri yöre halkı tarafından bu şekilde adlandırıldığı söylenmektedir.

Kocıbohcactniñyamı (Ulu.) Kocı bohcac+l+nın yan+l. Yörede "kayın ağacı" anlamında "bohcac" kelimesi kullanılmaktadır. Bölgede kayın ağaçlarının bulunduğu yaylanın adıdır.

Durnayaylası (Zfr.) Turna yayla+sı. Karabük- Ulus arasındaki sırt boyunun adıdır. Niçin bu şekilde adlandırıldığı bilinmemektedir.

Candarmamezaliiyaylası (Zfr.) Jandarma mezarlkk+l yayla+sı. Zafer köyünün Safranbolu ilçesine bağlı olduğu zamanlarda, çatışma sırasında bir jandarma askerinin vurulup buraya gömülmesi sebebiyle yöre halkı bu şekilde adlandırmaktadır.

Isırganlıkyaylası (Zfr.) Isırganlık yayla+sı. Katırovası'nın bitişiğindeki bulunan yaylanın adıdır. Yaylada ısırgan otlarının bulunması sebebiyle bu şekilde adlandırıldığı düşünülmektedir.

Böyükdüz (Zfr.) Büyük düz. Yarısı Karabük sınırları içinde yarısı Helkeme’ye ait olan yaylanın adıdır. Coğrafi yapısı gereği bu şekilde isimlendirildiği düşünülmektedir.

$10 \quad$ "Ulacaltı" olarak da adlandırılmaktadır.

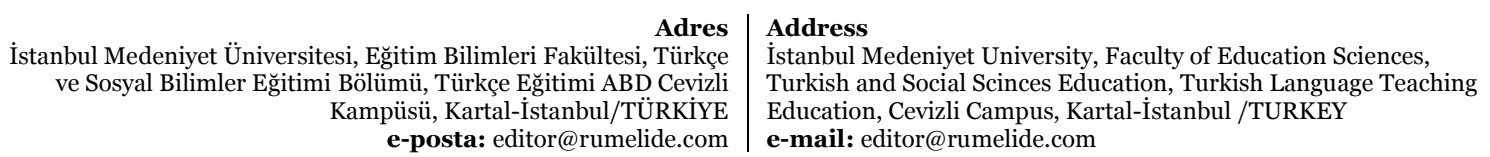


Sarıçiçekyaylası (Zfr.) Sarı çiçek yayla+sı. Yönü Safranbolu’ya bakan yaylanın adıdır. Yaylanın sarı çiçeklerle bezenmiş olması sebebiyle bu şekilde adlandırılmaktadır.

Yasıkköyyaylası (Zfr.) Yasık köy yayla+sı. Sarıçiçek ile Kıralcayaylası arasında yönü Karabük'e bakan yaylanın adıdır.

Sabandemürüyaylası (Zfr.) Saban demir+i yayla+sı. Sırt boyundaki yaylanın adıdır. Yöre halkı ismin verilme sebebiyle ilgili şöyle bir hikâyecik anlatır: Kimliği bilinmeyen bir kimse demir ustalığıyla bilinen Safranbolu'ya giderek hayvanlarının arkasına koymak için demir yaptırır. Hayvanların otladığı sırada demir sırtından düşer. Adam eve geldiğinde saban demirini bulamaz. Yaylaya tekrar gider. Hayvanlarını otlattığı yerlere tekrar bakarak saban demirini bulur. Bu olaydan sonra yöre halkı yaylayı söz konusu adla anmaya başlar.

Baklabostanyaylası (Zfr.) Bakla bostan yayla+sı. Büyükdüz’ün bitişiğindeki tarlanın adıdır.

Küçü̈kyazıyaylası (Zfr.) Küçük yazı yayla+sı. Safranbolu- Helkeme arasındaki sınır boyunda bulunan yaylanın adıdır. Niçin bu şekilde adlandırıldığı bilinmemektedir.

Grrngyaylası (Zfr.) Kırık yayla+sı. Yöre halkı iki hayvanı birbirine bağlayan kütük anlamında "bonduruk" kelimesini kullanmaktadır. Bu alanda böyle bir kütüğün kırılması yaylaya adını vermiştir.

Kıralcayaylası (Zfr.) Kıralca yayla+sı. Yasıkköyyaylası ile Candarmamezaliiyaylası'nın arasında bulunan yaylanın adıdır.

Garabaghkyaylası (Zfr.) Kara bağllk. Koyungölü’nün üstü Kokurdanyaylası’nın altındaki yaylanın adıdır. Yöre halkı tarafından "Garabaglık" adının burada yetişen otların yapraklarının kare olmasıyla ilgili olduğu rivayet edilir. Ormanda çalışanlar tarafından bu şekilde adlandırılmaktadır ${ }^{11}$.

\subsubsection{Orotoponimler}

Yaylaköyübayırı (Zfr.) Yayla köy+ü bayır+l. Yayla köyüne giden yolun adıdır. Yöre halkı yolun eğimli olması sebebiyle bu şekilde adlandırmaktadır.

Dereboğazı (Zfr.) Dere boğaz+ı. Fazlığlu Mahallesi'nden Kabuskalığlu Mahallesi'ne doğru gelen suyun adıdır. Yöre halkı, kar ya da yağmur yağdığı zaman oluşan su yolunu bu şekilde adlandırmaktadır.

Burunüstü (Zfr.) Burun üst+ü. Gölpınarı'ndan yukarı doğru Karacasuyu'na doğru giden yolun adıdır. Yöre halkı yolun T harfi şeklinde kuru, düz olan bir yer olduğunu söylemektedir.

Bıçakburnu (Zfr.) Bıçak bur(u)n+u. Çukur bir tarlada iki kenarın kesiştiği yerin adıdır.

Enviyeburnu (Zfr.) Enviye bur(u)n+u. Yöredeki birkaç ormana giden yolun üstündeki kesişim noktasının adıdır. Niçin bu şekilde adlandırıldığı kesin olarak bilinmemekle birlikte yöre halkı neredeyse oradaki tüm ormanlara gidilirken buradan geçmek zorunda olunduğu için bu şekilde adlandırıldığını söylemektedir.

\footnotetext{
$11 \quad$ Yöre halkı yayladaki bu bitkinin hayvanların da yemediği bir ot olduğunu söylemektedir.

\begin{tabular}{|c|c|}
\hline Adres & Address \\
\hline İstanbul Medeniyet Üniversitesi, Eğitim Bilimleri Fakültesi, Türkçe & İstanbul Medeniyet University, Faculty of Education Sciences, \\
\hline ve Sosyal Bilimler Eğitimi Bölümü, Türkçe Eğitimi ABD Cevizli & Turkish and Social Scinces Education, Turkish Language Teaching \\
\hline $\begin{array}{r}\text { Kampüsü, Kartal-İstanbul/TÜRKIYE } \\
\text { e-posta: editor@rumelide.com }\end{array}$ & $\begin{array}{l}\text { Education, Cevizli Campus, Kartal-İstanbul /TURKEY } \\
\text { e-mail: editor@rumelide.com }\end{array}$ \\
\hline
\end{tabular}
}


Gökceburnu (Zfr.) Gökçe bur(u)n+u. Yörede "kayın ağacı" anlamında "gökçe" kelimesi kullanılmaktadır. Bölge, kayın ağacının çok bitmesi sebebiyle bu şekilde adlandırılmaktadır².

Güñlükburnu (Ulu.) Günlük bur(u)n+u. Hisarköy ile Uluköy’ü ayıran sırt boyunun adıdır. Köründeğirmenyanı'ndan Uluköy’e kadar ilerler. Niçin bu şekilde adlandırıldığı bilinmemektedir.

Helkemeovası (Zfr.) Helkeme ova+sı. Helkeme Fabrikası'nın bulunduğu yerin adıdır.

Kattrovası (Zfr.) Katır ova+sı. Safranbolu- Helkeme yolu arasındaki ovanın adıdır. Yöre halkı ovayı hayvanlarını otlatmak, yorulunca dinlendirmek amacıyla kullanmaktadır. Eskiden bu ovayı özellikle katırlar kullanırmış. Bunun sebebi katırların diğer hayvanlardan daha fazla yük taşımasıdır. Adı, bu katırlardan yola çıkılarak verilmiştir.

Yanıggaya (Zfr.) Yanık kaya. Enviyeburnu'nun ilerisindeki büyük kayanın adıdır. Ağaç bitmeyen bu kayanın tepe kısmı güneşte yanarak kararmış, bu olay üzerine yöre halkı kayayı bu şekilde adlandırmıştır.

İnbaşıgayası (Zfr.) İnbaşı kaya+sı. Kamyon yolunun geçtiği mevkinin adıdır.

Dervetgayası (Zfr.) Dervet kaya+sı. Safranbolu patika yolu üzerindeki kayanın adıdır. Niçin bu şekilde adlandırıldığı bilinmemekle birlikte yöre halkı tarafından büyük kaya olarak nitelendirilir. Uluköy ve Hisar köylerinin suyu bu kayadan gelir.

Arrgayası (Ulu.) Arı kaya+sı. Uluköy'de bulunan uçuruma benzer büyük, yüksek kayanın adıdır. Yöre halkı bu kayayla ilgili çeşitli anlatılar aktarmıştır. İlk anlatı bu kayada bir hazine olduğu ve kimsenin heybetinden dolayı onu almaya cesaret edemediğine dairdir. Diğer bir anlatı ise bu kayanın tepesinde çok büyük bir arı kovanı olduğu hatta zamanında kayadan oluk oluk bal aktığı, adının da buradan geldiği şeklindedir.

Kırharman (Ulu.) Kır harman. Yöre halkı ekimi olmayan, verimsiz bir arazi olduğu için bu şekilde adlandırmaktadır.

Harmanalt (Zfr.) Harman alt $+\imath$. Verimsiz arazinin adıdır. Yöre halkı üst tarafını harmanlarını (tahıllarını) dövmek için kullanmaktadır. Alt tarafının da kırsal olması sebebiyle bu şekilde adlandırılmaktadır.

Kelebektarlası (Zfr.) Kelebek tarla+sı. Kelebek ağacının çok olması sebebiyle yöre halkı tarlayı bu şekilde adlandırmaktadır.

Karacasu (Zfr.) Karaca su. Yamaçta kalan kır tarlanın adıdır. Tarlanın yarı tarafında tarım yapılır yarı tarafı ise ekime elverişsiz kır alandır. Yöre halkı tarlada pınar bulunması sebebiyle bu şekilde adlandırmaktadır.

Hudut (Zfr.) Hudut. Safranbolu ile Ulus'u birbirinden ayıran sınırın adıdır.

Ucbuñar (Zfr.) Uç pınar. Zafer köyünün doğusunda yer alan Gökgözgırăğı'ndan başlayıp Ceyüplertepesi'ne kadar olan sırt boyunun adıdır.

\footnotetext{
12 Yöre halkı tarafından “Gökçeburnu” adının yanı sıra mevki için "Gökçeyogusu” adlandırması da kullanılmaktadır. 
The linguistic analysis of microtoponyms of Uluköy and Zafer villages in the district of Ulus in Bartın / A. Çelik; R. Uysal (pp. 151-169)

Çelikbaştepesi (Zfr.) Çelik baş tepe+si. Türbe pınarı yakınındaki tepenin adıdır. Yöre halkı bir zamanlar burada çobanların oyun oynadığını, bu oyunun ise taşa çelik dikip odunla çeliği devirmek şeklinde olduğunu söylemektedir. Bundan dolayı yöre halkı bu tepeyi çobanların oyunu ile ilişkilendirerek adlandırmıştır.

Sivricegayatepesi (Zfr.) Sivrice kaya tepe+si. Yüksek bir konumda bulunmaktadır ${ }^{13}$.

Kilseyanıtepesi (Zfr.) Kilise yanı tepe+si. Yöre halkı topraklarında Rumlar’ın yaşadığı dönemden kalma bir kilise olması sebebiyle bu şekilde adlandırmaktadır.

Konacukgırağı (Zfr.) Konacık kıraktı. Ardıç Ormanı'nın en yüksek tepesinin adıdır. Safranbolu ile Zafer köyü arasındaki tepedir. Niçin bu şekilde adlandırıldığı bilinmemektedir.

Kapahlıdă̆ (Zfr.) Kapakh dăğ. Bir yüzü Bartın-Karabük yoluna diğer yüzü Gökgözgırağı’na bakan tepenin adıdır.

Türbetepesi (Zfr.) Türbe tepe+si. Katırovası'nın üst tarafında bulunan tepenin adıdır.

Gülleyigtepesi (Zfr.) Gülleyik tepe+si. Gülleyigsuyu’nun bulunduğu tepenin adıdır.

Atakdibi (Ulu.) Atak dip+i. Uluköy Ömeră̆ Mahallesi’nde bulunan Ömeră̆ Camisi'nin karşındaki yerin adıdır.

Yardibi (Ulu.) Yar dip $+i$. Kirenpınarı'nın altındaki pınarın adıdır.

\subsubsection{Horotoponimler}

Gabuksayvam (Zfr.) Kabuk sayvan $+\imath$. Ormanda dönemsel olarak kalmak için yapılan yerin adıdır. Kimin tarafından yapıldığı bilinmemektedir. Ağaç kabuklarından yapılmış olması sebebiyle bu şekilde adlandırılmaktadır.

Kiler (Zfr.) Kiler. Buzağıların yattığı bir yerin adıdır¹4.

Goyunahır (Zfr.) Koyun ahır+l. Koyunların yattığı bir yerin adıdır.

Kömüşyată̆ı (Zfr.) Kömüş yatak+ı. Mandaların yattı̆̆ı bir yerin adıdır.

Çilyenüzüm (Zfr.) Çilyen üzüm. Küçük kara üzüm bağlarının adıdır.

Garaüzüm (Zfr.) Kara üzüm. Olgunlaşmış kara üzüm bağlarının adıdır.

Gögceüzüm (Zfr.) Gökçe üzüm. Sarı, yaprakları yeşil olan üzüm bağlarınınn adıdır.

Çavuşüzüm (Zfr.) Çavuş üzüm. İri taneli üzüm bağlarının adıdır.

Aşşaabagce (Zfr.) Aşağı bahçe. Bir bahçenin Kumluca tarafını gösteren bölümünün adıdır.

\footnotetext{
13 "Sivriburnu" adıyla da bilinmektedir. Tepenin yüksekte kalan kısmının yukarı doğru daralması sonucu oluşan görüntü sebebiyle bu şekilde adlandırılabilmiş olacă̆ı düşünülmektedir.

$14 \quad$ Yörede "Bızagahırı" adı da kullanılmaktadır.
}

\footnotetext{
Adres $\mid$ Address

İstanbul Medeniyet Üniversitesi, Eğitim Bilimleri Fakültesi, Türkçe İstanbul Medeniyet University, Faculty of Education Sciences,

ve Sosyal Bilimler Eğitimi Bölümü, Türkce Eğitimi ABD Cevizli Turkish and Social Scinces Education, Turkish Language Teaching

Kampüsü, Kartal-İstanbul/TÜRKIYY $\quad$ Education, Cevizli Campus, Kartal-İstanbul /TURKEY

e-posta: editor@rumelide.com 1 e-mail: editor@rumelide.com
} 
Yukarbbagce (Zfr.) Yukarı bahçe. Bir bahçenin Uluköy tarafını gösteren bölümünün adıdır. Bahçenin yukarı tarafının Uluköy’e bakması sebebiyle bu şekilde adlandırılmıştır.

Akçakirenbagce (Zfr.) Akça kiren bahçe. Yalnızca erik ağacının bulunduğu bir bahçenin adıdır. Abdalhızarı tarlasının çıkışındadır.

Ayınınçamlı̆̆ı (Ulu.) Ayı+nın çamlık+l. Uluköy ile Ömeră̆ Mahallesi'nin arasında yer alan çamlığın adidir.

Sarıçamlk (Zfr.) Sarı çamlık. Yöre halkı çamın cinsinden dolayı söz konusu yeri bu şekilde adlandırmaktadır.

Garaçamlk (Zfr.) Kara çamlı. Yöre halkı çamın cinsinden dolayı söz konusu yeri bu şekilde adlandırılmaktadır.

Aşşaaçayır (Zfr.) Aşă̆ı çayır. Tarım yapılmayan, hasat olmayan bir arazinin aşağı bölümünün adıdır.

Yukarçayır (Zfr.) Yukarı çayır. Ekimi olmayan, hayvanların otlatıldığı bir yerin adıdır. İletişimi kolaylaştırmak için bu şekilde adlandırıldığı düşünülmektedir.

Gölbuñarıçayırı (Zfr.) Göl pınar+ı çayır $+\imath$. Hayvanları otlatmak için ayrılan ekilmemiş bir tarlanın adıdır. Eskiden tarla olarak kullanılsa da zamanla yöre halkının ihtiyaçları doğrultusunda hayvanlar için çayır olarak bırakılması sebebiyle bu şekilde adlandırılmaktadır.

Çayırbaş (Ulu.) Çayır baş. Ömerağ Mahallesi’nde hayvanların otlatıldığı küçük arazinin adıdır.

Kilseyamı (Ulu.) Kilise yan+ı. Arıgayası'nın sağ tarafında hayvanların otlatılması için kullanılan bir tarlanın adıdır.

Isbagköytarlası (Ulu.) Isbag köy tarla+sı. Ömeră̆ Mahallesi'ndeki okulun üst tarafında bulunan tarlanın adıdır. Yöre halkı tarlanın Bizans döneminden beri kullanıldığını söylemektedir.

Arıglar (Ulu.) Arıglar. Günlükburnu sırtının arkasında kalan tarlanın adıdır. Yöre halkı eskiden bu sırtın arkasında da köylerin var olduğunu ancak bu köylerin zaman içinde yok olduğunu söylemektedir. Söz konusu adın yok olan köylerden birinin adı olduğu ve bu tarlanın adlandırılmasına kaynaklık ettiği dile getirilmiştir.

Değirmendaşıtarlası (Zfr.) Değirmen taş+ı tarla+sı. Kilseyanı'ndaki tarlanın adıdır. Bundan yaklaşık yüz yıl önce Kulaklar Mahallesi’ndeki bir değirmenin değirmen taşından yağmur suları sebebiyle kopan bir parçanın bu tarlaya sürüklendiği söylenmektedir. Tarla adını bu olaydan almıştır¹5.

Gortarlası (Zfr.) Kor tarla+sı. Düz, tarıma elverişli olan bir tarlanın adıdır.

Çukurtarla (Zfr.) Çukur tarla. Kimi yerleri düz kimi yerleri bayır olan bir tarlanın adıdır. Girintili çıııntılı olması sebebiyle bu şekilde adlandırılmaktadır.

15 "Değirmendaşıtarlası”, "Harmanaltı” adıyla da bilinmektedir.

\begin{tabular}{|c|c|}
\hline Adres & Address \\
\hline İstanbul Medeniyet Üniversitesi, Eğitim Bilimleri Fakültesi, Türkçe & İstanbul Medeniyet University, Faculty of Education Sciences, \\
\hline ve Sosyal Bilimler Eğitimi Bölümü, Türkçe Eğitimi ABD Cevizli & Turkish and Social Scinces Education, Turkish Language Teaching \\
\hline $\begin{array}{r}\text { Kampüsü, Kartal-İstanbul/TÜRKIYE } \\
\text { e-posta: editor@rumelide.com }\end{array}$ & $\begin{array}{l}\text { Education, Cevizli Campus, Kartal-İstanbul /TURKEY } \\
\text { e-mail: editor@rumelide.com }\end{array}$ \\
\hline
\end{tabular}




\section{Sonuç}

Çalışmada toplam 158 silikyeradı bulunmaktadır. Bu silikyeradlarının 13’ü birbiriyle koşuttur. Derlenen 158 silikyeradının 55’i hidronim (su adı), 34’ü oronim (dağ adı), 31’i agroonim (bağ adı), 23’ü oykonim (orun adı), 8’i horonim (el adı), ve 7'si drimonim (orman adı)'dir. Sayıca kendisine en çok rastlanan hidronim adlandırmaları yörenin suya verdiği önemi göstermektedir. Hidronimlerin 41’i potamonim, 9'u limnomonim, 4'ü helonimdir. Hidronimler kendi içinde sınıflandırıldığında toplam 41 potamonimin 3'ü çay adı, 12'si çeşme adı, 15’i dere adı, 11’i pınar adıdır. Limnomonimlerin ise 5’i göl, 5 ’i de kuyu adlarından oluşmaktadır. Helonimler incelendiğinde ise 4 bataklık adıyla karşılaşılır. Elde edilen sayısal verilerden yola çıkılarak potonimler içinde derelerin önemli bir yer tuttuğu ve limnonimler içinde ise kuyu ve göl isimlendirmelerinin eşit düzeyde yer aldığı söylenebilir.

Oronimler içinde en sık kullanılan ise 11 adet ile tepe adlarıdır. Diğer oronim türündeki yer adlarının ise sayıları 1 ile 5 arasında değişkenlik göstermektedir.

Toplam 31 adet agroonimin 4’ü bağ, 3’ü bahçe, 5’i çamlık, 5’i çayır, 14’ü ise tarladır. Sayısal veriler göz önünde bulundurulduğunda agroonimler içinde "tarla" adlarının önemli bir yere sahip olduğu görülür. Tarlalardan sonra "çamlık" ve "çayır" adları gelmektedir.

Toplam 23 adet oykonim derlenmiştir. Oykonimler sınıflandırılırken derleme bulguları göz önünde bulundurularak komonimler ve orpedyonimlerle sinırl tutulmuştur. Oykonimlerin 6'sı komonim, 17'si orpedyonimdir. Komonimlerin 1’i çiftlik, 2'si köy, 3’ü ören/harabe adıdır. Orpedyonimler içinde yayla adları geniş bir yer tutar.

Kaynak kişiler: Adil Turgut (72 Ulu.), Hasan Turgut (48 Ulu.), Mustafa Şenol (79 Zfr.), Osman Şenol (56 Zfr.) Erhan Şenol (25 Zfr.), Şaziye Şenol (45)

Kisaltmalar: Ulu.: Uluköy, Zfr.: Zafer Köyü.

\section{Kaynakça}

Barem, G. M. Q. (2018). Telafer mikrotoponimleri ve dil incelemesi. Yayımlanmamış Yüksek Lisans Tezi, İzmir: Ege Üniversitesi, Sosyal Bilimler Enstitüsü.

Erkol, F. (2013). Afyonkarahisar ili Çay ilçesinin mikrotoponimleri ve dil incelenmesi. Yayımlanmamış Yüksek Lisans Tezi. Afyonkarahisar: Afyon Kocatepe Üniversitesi, Sosyal Bilimler Enstitüsü.

Köse, S. (2014). İzmir Karaburun yöresi mikrotoponimleri ve dil incelemesi. Yayımlanmamış Yüksek Lisans Tezi, İzmir: Ege Üniversitesi Sosyal Bilimler Enstitüsü.

Kuşdemir, A. (2017). Yerköy mikrotoponimlerinde görülen coğrafi terimler. Kesit Akademi Dergisi. $3 / 12,510-529$.

Kuşdemir, A. (2017). Yerköy'de bitki adlarından oluşan yer adları. TÜBAR, XLI, 2017-Bahar, 195-206.

Şahin, İ. (2011). Yeradıbilimi araştırmalarında mikrotoponiminin yeri, önemi ve araştırma yöntemi: Tırnak köyü (İçel/Gülnar) örneği. Turkish Studies. 6/1: 1807-1830.

Şahin, İ. (2013). Türkiye yeradbiliminde terim ve tür sınıflandırması sorunları. Avrasya Terim Dergisi. $1 / 1,46-58$.

Şahin, İ. (2015). Türkiye yeradbiliminde leksik-semantik sınıflandırma meselesi. Avrasya Terim Dergisi. 1, 10-21.

Türk Dil Kurumu. (2020). Türk Dil Kurumu sözlükleri. Web: https://sozluk.gov.tr/ adresinden 30.09.2020 tarihinde alınmıştır.

\footnotetext{
Adres $\mid$ Address

İstanbul Medeniyet Üniversitesi, Eğitim Bilimleri Fakültesi, Türkçe ve Sosyal Bilimler Eğitimi Bölümü, Türkçe Eğitimi ABD Cevizli Turkish and Social Scinces Education, Turkish Language Teaching Kampüsü, Kartal-İstanbul/TÜRKIYE $\quad$ Education, Cevizli Campus, Kartal-İstanbul /TURKEY e-posta: editor@rumelide.com 1 e-mail: editor@rumelide.com
} 
Yağmur, Ö. (2014). Höbek köyü yer adları üzerine bir inceleme. İstanbul Üniversitesi Edebiyat Fakültesi Türk Dili ve Edebiyatı Dergisi. 49, 243-264.

Yılmaz, C.; Kaya, M. (2018). Bir mikrotoponimi denemesi; Sinop-Ayancık'ta Zingal Orman İşletmesi'nin yer adlarına etkisi. Doğu Coğrafya Dergisi. 23/39, 149-164.

Yorulmaz, Kahve, M. (2018). Muğla yeradları üzerine bir dil incelemesi -Menteşe'deki silikyeradları-. Yayımlanmamış Doktora Tezi. Muğla: Muğla Sıtkı Koçman Üniversitesi, Sosyal Bilimler Enstitüsü. 